\title{
Apakah Manajemen Laba dilakukan untuk Tax Planning atau untuk Menjadikan Laba Lebih Persisten?
}

\author{
Martdian Ratna Sari \\ Program Studi Akuntansi Bisnis, Sekolah Tinggi Manajemen PPM \\ Jl. Menteng Raya No.9, Kb. Sirih, Kec. Menteng, Kota Jakarta Pusat, Jakarta, Indonesia \\ martdianratnasari@gmail.com \\ Benediktus Tandya Pinasthika* \\ Program Studi Akuntansi Bisnis, Sekolah Tinggi Manajemen PPM \\ Jl. Menteng Raya No.9, Kb. Sirih, Kec. Menteng, Kota Jakarta Pusat, Jakarta, Indonesia \\ bpinasthika@gmail.com
}

Diterima: 09-02-2021

Disetujui: 16-06-2021

Dipublikasi: 30-06-2021

\begin{abstract}
ABSTRAK
Penelitian ini bertujuan untuk mengkaji bagaimana manajemen laba yang dilakukan perusahaan memengaruhi besaran pajak dan persistensi laba, khususnya dalam bisnis transportasi di Indonesia. Penelitian ini menjadi penting karena dalam Pedoman Standar Akuntansi Keuangan (PSAK) tidak diatur secara jelas batasan dalam melakukan manajemen laba, sehingga dapat menimbulkan berbagai potensi kecurangan yang akhirnya melanggar PSAK maupun Peraturan Undang-undang terkait penyajian laporan keuangan. Penelitian ini menggunakan perusahaan transportasi sebagai sampel, dengan jumlah data observasi sebanyak 70 laporan keuangan selama tahun 2014-2018, rentang waktu penelitian selama 5 tahun. Hasil penelitian ini membuktikan bahwa manajemen laba tidak berpengaruh terhadap tax planning dan persistensi laba dikarenakan metode pengakuan laba dari setiap perusahan yang berbeda. Peran dari agen menjadi kunci dari laba yang persisten sebagai sinyal kepada principal. Dari hasil penelitian ini, peneliti menduga bahwa aktivitas riil perusahaan merepresentasikan kondisi laba dan metode pengakuan tidak memiliki hubugan terhadap persistensi laba. Penulis menduga bahwa perusahaan tidak dapat melakukan manajemen laba dan tax planning secara bersamaan..
\end{abstract}

Kata Kunci:

Manajemen Laba; Pajak; Persistensi Laba

\begin{abstract}
This study aims to examine how the company's earnings management affects the amount of tax and earnings persistence, especially in the transportation business in Indonesia. This research is important because the Financial Accounting Standards Guidelines (PSAK) do not regulate the limits in managing earnings so that it can lead to various potential fraud that ultimately violates the PSAK and the Laws Regulations relating to the presentation of financial statements. This study uses a transportation company as a sample, with 70 observations of total financial data during 2014-2018, a span of 5 years. The results of this study prove that earnings management does not affect tax planning and earnings persistence due to the profit recognition method of each different company. The role of the agent is the key to persistent earnings as a signal to the principal. From the results of this study, researchers suspect that the real activity of companies represents the condition of earnings and the method of recognition has no relationship with earnings persistence. The author suspects that the company cannot do earnings management and tax planning simultaneously.
\end{abstract}

Keywords:

Earnings Management; Tax; Earning Persistenc 


\section{PENDAHULUAN}

Indonesia, sebagai negara yang diprediksi menjadi negara keempat di dunia pada tahun 2030, memiliki perkembangan industri transportasi yang baik. Menurut Supply Chain Indonesia (SCI) 2018, industri transportasi di Indonesia diprediksi tumbuh 11,15 persen sebesar Rp 740,4 triliun (kontribusi terhadap PDB) dari sebelumnya 8,23 persen atau senilai Rp 666,2 triliun. Nilai kontribusi angkutan darat adalah yang terbesar dalam pertumbuhan sektor jasa transportasi. Sementara kontribusi terkecil adalah angkutan berbasis kereta. Angkutan darat berkontribusi 51,43 persen atau senilai Rp 380,8 triliun dan angkutan udara berkontribusi sebesar 38,12 persen atau senilai Rp 282,2 triliun. Sedangkan angkutan laut berkontribusi sebesar 6,50 persen dan angkutan sungai, danau, dan penyebrangan sebesar 2,30 persen. Di posisi paling kecil adalah angkutan rel sebesar 1,66 persen. Hal ini tidak dapat lepas dari peningkatan kebutuhan jasa pengiriman barang yang melibatkan penjual dan pembeli secara daring (online). Walaupun angkutan darat dinilai berkontribusi tinggi, tingkat pertumbuhan tertinggi pada tahun 2019 diprediksi terjadi pada angkutan udara atau 17,37 persen dan angkutan rel senilai 17,11 persen.

Selain dinilai positif oleh SCI, infrastruktur transportasi Indonesia berada diperingkat 30 dari sebelumnya 36 dan terbaik ketiga di ASEAN. Namun, industri transportasi juga memiliki masalah keuangan, salah satunya PT Kereta Api Indonesia (PT KAI) pada tahun 2005, dimana laporan kinerja keuangan tahunan tersebut diumumkan bahwa PT KAI mendapatkan keuntungan sebesar Rp 6,90 milyar. Padahal sebenarnya mengalami kerugian sebesar Rp 63 milyar (Tempo.co.id, 2007 dalam Caesarriani, 2012). Oleh karena itu, Kementerian Keuangan pada 6 Juli 2007 membekukan izin akuntan publik Drs. Salam Mannan yang menjadi pemimpin rekan pada Kantor Akuntan Publik (KAP) S. Mannan, Sofwan, Adna dan Rekan.

Baru-baru ini, PT. Garuda Indonesia (Persero) menjadi sorotan media dikarenakan polemik audit laporan keuangan tahun buku 2018 yang melibatkan akuntan publik. Sehingga, Kementerian Keuangan terpaksa membekukan izin (surat tanda terdaftar/STTD) akuntan publik Kasner Sirumapea selama satu tahun karena akuntan publik tersebut dinilai melanggar standar professional dalam perumusan suatu opini dan pelaporan atas laporan keuangan dan terkait dengan lemahnya pengendalian mutu oleh KAP Tanubrata, Sutanto, Fahmi, Bambang \& Rekan (Harian Kompas, 28 Juni). Otoritas Jasa Keuangan (OJK) pun juga menjatuhi sanksi administratif kepada Garuda Indonesia sebesar Rp 100 juta dan semua anggota direksi dan dewan komisaris yang menandatangani laporan keuangan juga dikenai denda Rp 100 juta per orang. Bursa Efek Indonesia juga menjatuhkan sanksi berupa peringatan tertulis III dan denda Rp 250 juta kepada Garuda Indonesia, serta mewajibkan Garuda Indonesia untuk menyajikan ulang laporan keuangan 2018 dan laporan keuangan perusahaan triwulan I-2019, selambatlambatnya pada 26 Juli 2019. Sanksi-sanksi tersebut berdampak pada saham Garuda Indonesia yang anjlok 7,58 persen pada 28 Juni 2019 karena pasar merespons negatif.

Fungsi penyusunan laporan keuangan oleh perusahaan salah satunya digunakan sebagai dasar penilaian kinerja dan keadaan finansial (Suwandika dan Astika, 2013). Suwandika dan Astika (2013) 
menjelaskan bahwa laporan keuangan perusahaan selain ditujukan untuk kepentingan pemegang saham juga ditujukan untuk kepentingan perpajakan, sehingga untuk perhitungan pajak perusahaan harus membuat laporan keuangan fiskal. Dalam dunia akuntansi, kasus-kasus di atas dikenal dengan creative accounting yang terkait dengan financial numbers game, yang terdiri atas aggressive accounting, earnings management, income smoothing, fraudulent financial reporting, dan creative accounting (Mulford dan Comiskey, 2002).

Manajemen laba adalah manipulasi laba yang dilakukan pihak manajemen untuk mencapai tujuan-tujuan tertentu. Manipulasi dilakukan agar laba tampak sebagaimana yang diharapkan (Fern et al, 1994). Manajemen laba akan meningkatkan laba akuntansi, sehingga laba fiskal juga akan meningkat (Syanthi et al, 2012). Hal ini bisa terjadi karena manajemen laba dapat didefinisikan sebagai manipulasi dari kinerja ekonomi perusahaan secara sengaja untuk menyesatkan stakeholders atau untuk mempengaruhi hasil kontrak yang bergantung pada angka akuntansi yang telah dilaporkan (Mechelli dan Cimini, 2013). Setiap perusahaan pada saat ini sangat memperhatikan hasil laporan keuangan perusahaannya, karena dengan laporan keuangan yang baik dan bisa menghasilkan laba maksimal yang akan dapat menarik para investor bergabung untuk menginvestasikan modalnya bagi perusahaan tersebut (Agustina dan Ahmar, 2014).

Di sisi lain, manajemen laba yang didefiniskan sebagai bentuk manipulasi, laba memiliki hubungan dengan tax planning atau perencanaan pajak. Untuk meningkatkan efisiensi dan sisi kompetitif, perusahaan akan mengurangi biaya seoptimal mungkin (Puspita, 2019). Apabila laba dapat direncanakan sedemikian rupa, hal ini akan berimbas pada pajak yang dikeluarkan, terlebih perusahaan cenderung ingin membayar pajak serendah-rendahnya karena pajak termasuk salah satu komponen biaya. Laba yang sudah didesain tersebut juga dapat dinilai melalui kualitasnya, apakah baik atau buruk.

Kegiatan manajemen laba, tentunya tidak dapat dibatasi atau dihentikan praktek penyalahgunaannya dan penggunaan yang tidak tepat, walau sudah menipu auditor dan regulator di masa lalu seperti kasus Enron, Bank Punjab, dan hal ini akan terus berlanjut dengan kondisi yang sama (Shah et al, 2011). Penulis merasa bahwa penelitian ini menjadi penting, apalagi bila dilihat dari kecenderungan yang terjadi seperti kasus terbaru PT Garuda Indonesia. Manajemen laba patut menjadi urgensi dalam penelitian ini, terlebih berkaca pada kasus-kasus di masa lalu yang tidak hanya merugikan perusahaan itu sendiri, bahkan bisa merugikan negara, bilamana perusahaan tersebut adalah Badan Usaha Milik Negara (BUMN). Maka dari itu, penelitian ini mencoba untuk membuktikan apakah manajemen laba dilakukan untuk sekedar mengatur pajak perusahaan atau untuk menjadikan laba perusahaan lebih persisten. Dan lebih jauh penelitian ini mencoba melihat bagaimana pengaruh manajemen laba dengan berbagai skema yang dilakukan perusahaan terhadap tax planning dan persistensi laba, mengacu pada signaling theory.

Hasil penelitian ini memiliki implikasi praktis terutama kepada manajer dalam upaya mengelola keuangan perusahaan, tidak hanya sebagai perhatian pada laba di laporan keuangan tetapi juga memperhatikan standar akuntansi yang berlaku. Dalam hal ini, akuntan diharapkan memiliki 
peranan penting untuk berpegang pada prinsip-prinsip akuntansi agar tidak terjadi pelanggaran secara undang-undang, terkhusus pada pengakuan laba. Terbukti dalam penelitian ini bahwa semua perusahaan setiap tahunnya melakukan manajemen laba yang dampak jangka panjangnya dapat menimbulkan potensi salah saji laporan keuangan yang besar.

\section{Signaling Theory}

Secara definitif, signaling theory berguna untuk menjelaskan perilaku ketika dua pihak (baik individu atau organisasi) memiliki akses terhadap informasi yang berbeda (Connelly et al, 2011). Secara khusus, satu pihak yang menjadi pengirim pesan harus memilih cara berkomunikasi (atau memberikan sinyal) soal informasi tersebut. Pihak lain yang menjadi penerima harus memilih cara menginterpretasikan sinyal yang diberikan oleh pengirim. Sinyal merupakan tindakan atau pernyataan seseorang atau perusahaan atau intensi dan mengungkapkan berbagai informasi, termasuk pasar yang kompetitif, kualitas produk atau layanan, ketidakpastiaan perusahaan asuransi atas kesehatan pembeli asuransi, atau kualitas kumpulan tenaga kerja (Whelan dan Demangeot, 2015).

Menurut Connelly et al (2011), signaling theory berfokus pada pada komunikasi yang disengaja dan memiliki tujuan positif dalam atribut organisasi. Sebagai contoh, menerbitkan saham baru dapat diartikan sebagai sinyal negatif karena manajemen mungkin akan menerbitkan ekuitas ketika mereka percaya harga saham perusahaan mereka terlalu tinggi (Myers dan Majluf, 1984). Hal ini penting untuk dicatat, bahwa orang dalam tidak mengirimkan sinyal negatif ke orang luar dengan tujuan mengurangi asimetri informasi, tetapi hal ini merupakan konsekuensi yang tidak diinginkan dari tindakan orang dalam tersebut.

Seiring dengan signaling theory, manajemen selaku agen perusahaan juga menginginkan perusahaannya dinilai baik, maka dari itu membuat laporan keuangan yang baik menjadi salah satu cara untuk memberikan sinyal positif atas kinerja perusahaan. Laporan keuangan yang disajikan secara baik akan meningkatkan nilai perusahaan yang positif pula.

\section{Agency Theory}

Menurut Shailer (2018), agency theory melihat masalah yang muncul ketika salah satu pihak (agen) diharapkan untuk bertindak bagi kepentingan pihak lain (principal), tetapi kepentingan agen sendiri dapat bertentangan dengan kepentingan principal dan principal tidak dapat sepenuhnya memantau dan mendisplinkan agen. Hal ini biasa disebut sebagai principal-agent problem dan terkait dengan agency cost yang merupakan biaya yang ditanggung oleh salah satu pihak (bisa agen ataupun principal) sebagai konsekuensi dari masalah agensi tersebut.

Implikasi dari adanya asimiteri informasi antara manajer sebagai agen dan pemilik (pemegang saham) sebagai principal dijelaskan melalui agency theory (Syanthi et al, 2012). Menurut Jiraporn et al (2008), perspektif agency theory membedakan antara sifat opurtunistik dan kebermanfaatan dalam menggunakan manajemen laba. Bukti empiris menunjukkan bahwa perusahaan tempat manajemen laba terjadi pada tingkat yang lebih besar (kecil), menanggung lebih sedikit (banyak) agency cost. Jika 
manajemen laba digunakan secara opurtunistik oleh manajer, perusahaan yang memiliki agency cost yang lebih parah akan menunjukkan tingkat manajemen laba yang lebih tinggi. Dalam kata lain, tingkat manajemen laba, secara positif, terkait dengan konflik agensi.

\section{Manajemen Laba}

Manajemen laba adalah pilihan dalam kebijakan akuntansi atau tindakan konkret yang mengakibatkan laba bisa disesuaikan dengan tujuan pelaporan dalam laporan keuangan (Scott, 2015). Manajemen laba yang dikelola dengan kebijakan akuntansi disebut manajemen laba akrual dan manajemen laba yang dikelola dengan memperhatikan operasional riil perusahaan disebut manajemen laba riil.

Menurut Darmawan et al (2019), manajemen laba dapat terjadi ketika manajer menggunakan valuasi dan menyusun transkasi untuk merubah laporan keuangan sehingga beberapa pihak salah mengartikan performa ekonomi perusahaan atau mempegaruhi perjanjian kontrak yang tergantung pada angka akuntansi. Toumeh dan Yahya (2019) menjelaskan setidaknya tujuh teknik popular dalam manajemen laba, yaitu:

\section{Improper Revenue Recognition}

Dilaporkan bahwa ada beberapa perusahaan mengakui pendapatan lebih awal dan sebelum menyelesaikan kewajiban kinerja berdasarkan kontrak. Hal ini dapat dicapai dengan mencatat penjualan di masa mendatang pada hari terakhir periode berjalan untuk meningkatkan pendapatan mereka.

\section{The Big Bath}

Penghapusan asset secara besar-besaran serta kewajiban akrual dalam upaya membuat neraca konservatif sehingga akan ada lebih sedikit pengeluaran untuk dijadikan hambatan pada pendapatan masa depan.

\section{Income Smoothing}

Komponen manajemen laba yang menciptakan pertumbuhan pendapatan secara konsisten, yang dihasilkan oleh akuntansi akrual seperti alokasi biaya kapitalisasi menggunakan metode garis lurus seiring waktu sebagai pengeluaran.

\section{Cookie Jar Reserves}

Manajer mengurangi biaya tahun depan dengan membalikkan bagian untuk menggembungkan laba tahun berikutnya dengan mengorbankan tahun berjalan.

\section{Big Bet on The Future}

Perusahaan dapat melakukan taruhan besar di masa depan melalui mengakuisisi perusahaan lain untuk mendapatkan investasi yang baik dari itu.

\section{Introducing New Standards}

Permintaan untuk mengembangkan standar akuntansi yang ada berasal dari perubahan lingkungan bisnis dan meningkatnya kompleksitas di pasar modal. Hal ini mengarah pada 
penerbitan standar akuntansi baru dengan aturan dan panduan baru. Biasanya dibutuhkan dua hingga tiga tahun untuk menerapkan standar di mana masalahnya adalah bahwa sebagian besar standar ini datang dengan aplikasi awal sukarela yang dapat membuka pintu bagi manajemen untuk memanipulasi pendapatan mereka.

\section{Depreciation, Amortization, And Depletion (DAD)}

IAS 16 Property, Plant, and Equipment mensyaratkan bahwa aset tidak lancar harus disusutkan selama masa manfaatnya. Aset tidak berwujud seperti merek dagang harus diamortisasi sementara sumber daya alam seperti minyak dan gas bumi mengalami proses kehabisan. Itemitem tersebut memerlukan penilaian diskresi oleh manajemen untuk memilih metode penyusutan (misalnya metode garis lurus dan pengurangan saldo), untuk memilih masa manfaat aset dan untuk memperkirakan nilai sisa. Perubahan dalam masa manfaat aset tidak lancar mempengaruhi laba yang dilaporkan dalam laporan laba rugi yang dapat dianggap sebagai manipulasi pendapatan.

Studi menjelaskan bahwa ketika manajemen laba dilakukan dengan mengikuti standar akuntansi maka dapat dikatakan sebagai manajemen laba yang absah, selain itu, dapat dikatakan sebagai fraud.

\section{Tax Planning}

Puspita (2019), menjelaskan bahwa tax planning merupakan praktik mengevaluasi dampak pajak dari tindakan atau transaksi yang terintegrasi, sementara dinyatakan bahwa "Tax Planning adalah proses mempertimbangkan semua faktor pajak yang terkait, dengan mempertimbangkan faktor material bukan pajak, untuk tujuan menentukan apakah dan juga, bagaimana, dan dengan siapa, untuk mengadakan dan melakukan transaksi, operasi, dan hubungan, dengan tujuan menghasilkan pajak serendah mungkin sambil mencapai tujuan bisnis, kepentingan pribadi, dan lainnya yang diinginkan. Tax planning adalah analisis sistematis untuk menunda opsi pajak yang ditujukan untuk meminimalkan kewajiban pajak pada periode pajak saat ini dan masa depan.

Aditama dan Purwaningsih (2014) menjelaskan bahwa ada beberapa cara yang dapat dilakukan oleh Wajib Pajak untuk meminimalkan beban pajak, di antaranya yaitu:

1. Pergeseran pajak (tax shifting) adalah pemindahan atau mentransfer beban pajak dari subjek pajak kepada pihak lainnya. Dengan demikian, orang atau badan yang dikenakan pajak dimungkinkan sekali tidak menanggung beban pajaknya.

2. Kapitalisasi adalah pengurangan harga objek pajak sama dengan jumlah pajak yang akan dibayarkan kemudian oleh pihak pembeli.

3. Transformasi adalah cara pengelakan pajak yang dilakukan oleh perusahaan dengan cara menanggung beban pajak yang dikenakan terhadapnya.

4. Penggelapan pajak (tax evasion) adalah penghindaran pajak yang dilakukan secara sengaja oleh wajib pajak dengan melanggar ketentuan perpajakan yang berlaku. Penggelapan pajak (tax 
evasion) dilakukan dengan cara memanipulasi secara illegal beban pajak dengan tidak melaporkan sebagian dari penghasilan, sehingga dapat memperkecil jumlah pajak terutang yang sebenarnya.

5. Penghindaran Pajak (Tax Avoidance) adalah usaha wajib pajak untuk meminimalkan beban pajak dengan cara menggunakan alternatif-alternatif yang riil yang dapat diterima oleh fiskus.

\section{Persistensi Laba}

Manajemen laba memiliki banyak kesamaan dengan kualitas laba (Lo, 2007). Hsu dan $\mathrm{Hu}$ (2015), menjelaskan bahwa kualitas laba didefinisikan sebagai fungsi dari sistem akuntansi yang mengkonversi kinerja keuangan fundamental menjadi angka akuntansi. Lo (2007) berpikir sebagian besar orang akan sangat setuju bahwa penghasilan yang dikelola memiliki kualitas rendah. Namun, kurangnya manajemen laba tidak cukup untuk menjamin pendapatan berkualitas tinggi, karena faktorfaktor lain berkontribusi dengan kualitas penghasilan. Sebagai contoh, akuntan dengan hati-hati mengikuti serangkaian standar yang buruk akan menghasilkan laporan keuangan berkualitas rendah. Namun demikian, jika ada faktor-faktor kontribusi konstan, maka dapat ditarik hubungan yang lebih dekat antara manajemen laba dan kualitas laba. Ball dan Shivakumar (2008) menjelaskan bahwa pendapatan berkualitas tinggi itu konservatif, sementara pendapatan berkualitas rendah adalah pendapatan yang sengaja dinaikkan.

\section{Manajemen Laba dan Tax Planning}

Lembaga keuangan berada di sektor-sektor di mana manajer harus menyeimbangkan insentif pelaporan keuangan dengan peraturan sebagai batasnya. Misalnya, studi tentang lembaga keuangan yang diatur dengan regulasi menunjukkan bahwa manajer menghadapi banyak insentif untuk mengelola pendapatan. Secara khusus, studi ini menunjukkan bahwa insentif yang terkait dengan pengurangan pajak yang terkait dengan peningkatan pendapatan (Beneish, 2001). Studi ini umumnya memberikan bukti yang konsisten dengan income smoothing. Oleh karena itu, dapat dipastikan bahwa mengatur atau melakukan manajemen laba memiliki dampak terhadap tax planning karena perencanaan pajak muncul dari perencanaan laba. Hubungan laba dan pajak adalah positif dan saling mempengaruhi satu sama lain. Nilai laba menjadi instrumen penting karena menjadi sinyal dari agen kepada principal atas persistensi laba (Jiraporn et al, 2008). Hal ini dapat ditunjukkan dengan pengaturan pajak sehingga nilai pajak yang disetorkan menjadi sekecil mungkin dan nilai laba menjadi terlihat lebih tinggi.

$\mathrm{H}_{1}$ : Manajemen laba memengaruhi tax planning di industri transportasi di Indonesia.

\section{Manajemen Laba dan Persistensi Laba}

Laba dapat menjadi persisten atau bersinambung apabila tidak terjadi shock pada ekonomi dan masalah pada penentuan laba (Frankel dan Litov, 2008). Hal ini dapat menunjukkan bahwa manajemen laba memiliki hubungan dengan persistensi laba, apakah persisten atau tidak. Hubungan ini menjadi positif apabila performa perusahaan dinilai baik dan laba ditentukan menggunakan metode yang normal. Mengatur atau melakukan manajemen laba dapat berpengaruh terhadap persistensi laba karena 
laba menjadi tidak persisten. Manajemen laba yang menjadi acuan adalah manajemen laba akrual atau metode pencatatan akuntansi dan manajemen laba riil yang berasal dari aktivitas operasi perusahaan. Kedua pendekatan tersebut menunjukkan bahwa terdapat peran manajerial yang ingin mengatur laba menjadi lebih tinggi atau lebih rendah untuk kepentingan memberi sinyal yang baik terhadap prinsipal (Darmawan et al, 2019).

$\mathrm{H}_{2}$ : Manajemen laba memengaruhi persistensi laba di industri transportasi di Indonesia.

\section{METODE RISET}

\section{Jenis Penelitian}

Jenis penelitian ini adalah penelitian kuantitatif-ekplanatif dimana, menurut Marczyk et al (2005), penelitian ini melibatkan studi yang menggunakan analisis statistik untuk mendapatkan temuannya dan meliputi pengukuran formal dan sistemastis melalui uji statistik. Penelitian ekplanatif hanya berusaha untuk membuktikan pengaruh antar variabel independen dengan variabel dependen.

\section{Data dan Sumber Data}

Penelitian ini menggunakan jenis data sekunder, dimana data primer telah diolah oleh pihak pengumpul data, dalam hal ini perusahaan yang menjadi sampel, dan disajikan dengan baik, berupa laporan keuangan tahunan dan laporan keuangan perusahaan di sektor industri transportasi, terdaftar di Bursa Efek Indonesia (BEI), telah diaudit, dan dipublikasikan melalui situs BEI yaitu www.idx.co.id. Metode pengumpulan data adalah dengan mengambil data sekunder, dalam hal ini laporan keuangan, selama 5 tahun berturut-turut sesuai dengan variabel yang ada. Dua metode tersebut dinilai penting dalam pengumpulan data karena menjadi salah satu tolak ukur dari keberhasilan penelitian ini.

\section{Populasi dan Sampel}

Dalam penelitian ini, populasi yag dimaksud adalah perusahaan yang termasuk ke dalam sektor industri transportasi dan terdaftar di Bursa Efek Indonesia. Sedangkan sampel adalah populasi spesifik yang ditetapkan untuk diteliti, dengan cara menetapkan sampel yang tepat dengan menentukan kriteria yang tepat untuk memilih sampel tersebut. Teknik pengambilan sampel yang digunakan dalam penelitian ini adalah purposive sampling, yaitu pengambilan sampel dengan menentukan kriteria khusus dan didasarkan pada tujuan penelitian. Oleh karena itu, kriteria tersebut dalam penelitian ini adalah sebagai berikut:

1. Perusahaan sektor industri transportasi yang terdaftar dan menerbitkan laporan tahunan dan laporan keuangan tahunan yang sudah diaudit pada situs BEI tahun 2014-2018

2. Perusahaan yang tidak delisting selama periode penelitian tahun 014-2018

3. Perusahaan memiliki kelengkapan data keuangan tahun 2014-2018 yang sesuai dengan variabel. 
Sampel yang diambil adalah laporan keuangan dengan jangka waktu 5 tahun dari 2014-2018 dikarenakan dalam menilai manajemen laba yang dilakukan, biasanya perusahaan melakukannya lebih dari 1 tahun atau dengan kata lain manajemen laba sudah dilakukan selama bertahun-tahun.

\section{Variabel dan Definisi Operasional}

Menurut Syanthi et al (2012), laba akuntansi adalah selisih pendapatan dan keuntungan setelah dikurangi beban dan kerugian. Persamaannya adalah sebagai berikut (Hanlon, 2005):

\section{Persistensi Laba}

$\mathrm{PTBI}_{\mathrm{t}+1}=\alpha_{0}+\alpha_{1} \mathrm{PTBI}_{1}+\varepsilon_{\mathrm{t}+1}$ ...(1)

Keterangan:

PTBI $_{\mathrm{t}+1}$ : pre-tax book income pada periode $\mathrm{t}+1$

$\mathrm{PTBI}_{1}$ : pre-tax book income pada periode $\mathrm{t}$

$\varepsilon:$ error term

\section{Manajemen Laba}

Menurut Syanthi et al (2012), manajemen laba adalah kebijakan akuntansi atau tindakantindakan yang dipilih oleh manajer untuk mencapai beberapa tujuan khusus dalam pelaporan laba, dimana dibagi menjadi manajemen laba akrual dan manajemen laba riil.

1. Manajemen Laba Akrual

Manajemen laba akrual adalah bentuk manajemen laba yang dilakukan dengan memanfaatkan kebebasan dalam memilih kebijakan akuntansi. Model perhitungannya adalah sebagai berikut (Khotari et al, 2005): Model perhitungan discretionary accruals menggunakan model performance matched discretionary accruals

$\mathrm{TACC}_{\mathrm{jt}}=\mathrm{NIBE}_{\mathrm{jt}} \mathrm{CFOO}_{\mathrm{jt}}$ (2)

$\mathrm{TACC}_{\mathrm{j} t} / \mathrm{TA}_{\mathrm{jt}-1}=\beta_{1}\left(1 / \mathrm{TA}_{\mathrm{jt}-1}\right)+\beta_{2}\left(\Delta \mathrm{REV}_{\mathrm{j} t} / \mathrm{TA}_{\mathrm{jt}-1}\right)+\beta_{3}\left(\mathrm{PPE}_{\mathrm{j} /} / \mathrm{TA}_{\mathrm{jt}-1}\right)+\beta_{4}\left(\mathrm{ROA}_{\mathrm{j} t} / \mathrm{TA}_{\mathrm{jt} 1}\right)+\varepsilon_{\mathrm{jt} \ldots \ldots \ldots .(3)}$ non-discretionary accruals

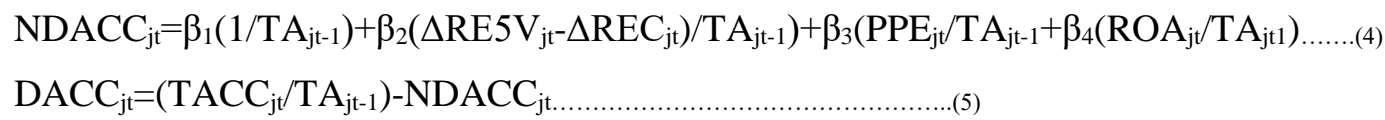

Keterangan:

TACC $_{\mathrm{jt}}$ : Total akrual perusahaan $\mathrm{j}$ pada periode $\mathrm{t}$

$\mathrm{NIBE}_{\mathrm{jt}} \quad$ : Net income before extraordinary item perusahaan $\mathrm{j}$ pada periode $\mathrm{t}$

$\mathrm{CFO}_{\mathrm{jt}} \quad$ : Operating cash flow perusahaan j pada periode t

$\mathrm{TA}_{\mathrm{jt}-1} \quad$ : Total aset perusahaan $\mathrm{j}$ pada periode $\mathrm{t}$

$\triangle \mathrm{REV}_{\mathrm{jt}}$ : Perubahan pendapatan perusahaan $\mathrm{j}$ pada periode $\mathrm{t}$

$\mathrm{PPE}_{\mathrm{jt}} \quad$ : Nilai aset tetap bersih perusahaan $\mathrm{j}$ pada periode $\mathrm{t}$

$\mathrm{ROA}_{\mathrm{jt}} \quad$ : Return on assets perusahaan $\mathrm{j}$ pada periode $\mathrm{t}$

$\mathrm{NDACC}_{\mathrm{jt}}$ : Non-discretionary accruals perusahaan j pada periode $\mathrm{t}$

$\triangle \mathrm{REC}_{\mathrm{jt}}$ : Perubahan piutang usaha perusahaan $\mathrm{j}$ pada periode $\mathrm{t}$ 
$\mathrm{DACC}_{\mathrm{jt}}$ : Discretionary accruals perusahaan $\mathrm{j}$ pada periode $\mathrm{t}$

2. Manajemen laba riil

Manajemen laba riil adalah bentuk manajemen laba yang dilakukan melalui manipulasi aktivitas operasional perusahaan. Model persamaannya adalah sebagai berikut (Roychowdhury, 2006).

\section{Abnomal cash flow from operations}

$\mathrm{CFO}_{\mathrm{j} t} / \mathrm{A}_{\mathrm{jt}-1}=\alpha_{0}+\alpha_{1}\left(1 / \mathrm{A}_{\mathrm{jt}-1}\right)+\beta_{1}\left(\mathrm{~S}_{\mathrm{t}} / \mathrm{A}_{\mathrm{jt}-1}\right)+\beta_{2}\left(\Delta \mathrm{S}_{\mathrm{j} t} / \mathrm{A}_{\mathrm{jt} 1}\right)+\varepsilon_{\mathrm{jt} .}$

\section{Abnormal Production Costs}

Normal COGS:

$\operatorname{COGS}_{\mathrm{j} t} / \mathrm{Aj}_{\mathrm{t}-1}=\alpha_{0}+\alpha_{1}\left(1 / \mathrm{A}_{\mathrm{jt}-1}\right)+\beta_{1}\left(\mathrm{~S}_{\mathrm{j}} / \mathrm{A}_{\mathrm{jt}-1}\right)+\varepsilon_{\mathrm{jt} .}$ $\ldots(7)$

Normal $\triangle I N V$ :

$\Delta \mathrm{INV}_{\mathrm{j} t} / \mathrm{A}_{\mathrm{jt}-1}=\alpha_{0}+\alpha_{1}\left(1 / \mathrm{A}_{\mathrm{jt}-1}\right)+\beta_{1}\left(\Delta \mathrm{S}_{\mathrm{j} t} / \mathrm{A}_{\mathrm{jt}-1}\right)+\beta_{2}\left(\Delta \mathrm{S}_{\mathrm{jt}-1} / \mathrm{A}_{\mathrm{jt} 1}\right)+\varepsilon_{\mathrm{jt} .}$

Normal production costs:

$\operatorname{PROD}_{\mathrm{j} t} / \mathrm{A}_{\mathrm{jt}-1}=\alpha_{0}+\alpha_{1}\left(1 / \mathrm{A}_{\mathrm{jt}-1}\right)+\beta_{1}\left(\mathrm{~S}_{\mathrm{j} t} / \mathrm{A}_{\mathrm{jt}-1}\right)+\beta_{2}\left(\Delta \mathrm{S}_{\mathrm{j} t} / \mathrm{A}_{\mathrm{jt}-1}\right)+\beta_{3}\left(\Delta \mathrm{S}_{\mathrm{jt}-1} / \mathrm{A}_{\mathrm{jt}-1}\right)+\varepsilon_{\mathrm{jt} t}$

\section{Abnormal Discretionary Expenses}

Normal discretionary expenses:

$\operatorname{DISEXP} \mathrm{j}_{\mathrm{j} t} / \mathrm{A}_{\mathrm{jt}-1}=\alpha_{0}+\alpha_{1}\left(1 / \mathrm{A}_{\mathrm{jt}-1}\right)+\beta_{1}\left(\mathrm{~S}_{\mathrm{jt}-1} / \mathrm{A}_{\mathrm{t}-1}\right)+\varepsilon_{\mathrm{jt} .}$ (10)

Keterangan:

$\mathrm{CFO}_{\mathrm{jt}} \quad$ : Arus kas operasi perusahaan j pada periode $\mathrm{t}$.

COGS $_{\mathrm{jt}}$ : Harga pokok penjualan perusahaan $\mathrm{j}$ pada periode $\mathrm{t}$.

$\Delta \mathrm{INV}_{\mathrm{jt}} \quad$ : Perubahan persediaan perusahaan $\mathrm{j}$ pada periode $\mathrm{t}$.

PROD $_{\mathrm{jt}}$ : Beban produksi perusahaan $\mathrm{j}$ pada periode $\mathrm{t}$.

DISEXP $_{\mathrm{jt}}$ : Pengeluaran diskresi perusahaan $\mathrm{j}$ pada periode $\mathrm{t}$.

$\mathrm{S}_{\mathrm{jt}} \quad$ : Penjualan perusahaan j pada periode $\mathrm{t}$.

$\Delta \mathrm{S}_{\mathrm{jt}} \quad$ : Perubahan penjualan perusahaan j pada periode $\mathrm{t}$.

$\Delta \mathrm{Sj}_{\mathrm{t}-1} \quad$ : Perubahan penjualan perusahaan $\mathrm{j}$ pada periode $\mathrm{t}-1$.

$\mathrm{Aj}_{\mathrm{t}-1} \quad$ : Total aset perusahaan $\mathrm{j}$ pada periode $\mathrm{t}-1$.

\section{Tax Planning}

Menurut Syanthi et al (2012), tax planning adalah langkah yang ditempuh oleh wajib pajak untuk meminimumkan beban pajak tahun berjalan maupun tahun yang akan datang, agar pajak yang dibayar dapat ditekan seefisien mungkin dan dengan berbagai cara yang memenuhi ketentuan perpajakan. Model persamaannya adalah sebagai berikut (Chen et al., 2007):

CurETRjt $=\frac{\left(\sum_{m}^{t}=t-4 \text { CTEjm }-\sum_{m}^{t}=t-4 \text { DTEjm }\right)}{\sum_{m}^{t}=t-4 \text { PTBIjm }}$

Keterangan:

CurETRjt: Current efective tax rate perusahaan $\mathrm{j}$ pada periode $\mathrm{t}$. 
$\sum_{m}^{t}=t-4$ CTEjm : Jumlah current tax expense perusahaan $\mathrm{j}$ selama 5 tahun dari periode $\mathrm{t}-4$ sampai periode t.

$\sum_{m}^{t}=t-4$ DTEjm: Jumlah deferred tax expense perusahaan $\mathrm{j}$ selama 5 tahun dari periode $\mathrm{t}-4$ sampai periode $\mathrm{t}$.

$\sum_{m}^{t}=t-4$ PTBIjm : Jumlah pre-tax book income perusahaan $\mathrm{j}$ selama 5 tahun dari periode $\mathrm{t}-4$ sampai periode $t$.

\section{Model Estimasi Regresi Berganda yang digunakan:}

TaxPlan ${ }_{\mathrm{t}}=\alpha_{0}+\alpha_{1}$ Abn.CFO ${ }_{\mathrm{t}}+\alpha_{2}$ Abn.PROD ${ }_{\mathrm{t}}+\alpha_{3}$ Abn.DISEXP $\mathrm{t}_{\mathrm{t}}+\alpha_{4} \mathrm{DACC}_{\mathrm{t}}+\alpha_{5} \mathrm{SIZE}_{\mathrm{t}}+\varepsilon_{\mathrm{t}+1 \ldots . .(12)}$

PTBI $_{\mathrm{t}+1}=\alpha_{0}+\alpha_{1}$ Abn.CFO ${ }_{\mathrm{t}}+\alpha_{2}$ Abn.PROD ${ }_{\mathrm{t}}+\alpha_{3} \mathrm{Abn}$.DISEXP $\mathrm{P}_{\mathrm{t}}+\alpha_{4} \mathrm{DACC}_{\mathrm{t}}+\alpha_{5} \mathrm{SIZE}_{\mathrm{t}}+\varepsilon_{\mathrm{t}+1 \ldots \ldots .(13)}$

Keterangan:

PTBI $_{t+1} \quad$ : Persistensi laba satu periode ke depan.

$\alpha_{0} \quad$ : koefisien konstanta.

$\alpha_{1}-\alpha_{6} \quad$ : koefisien variabel bebas.

Abn.CFO $\quad$ : Abnormal Cash Flow from Operation.

Abn.PROD $_{\mathrm{t}}$ : Abnormal Production Cost.

Abn.DISEXP $\mathrm{t}_{\mathrm{t}}$ : Abnormal Discretionary Expenses.

DACC $_{\mathrm{t}} \quad$ : Discretionary Accruals.

TaxPlan $_{\mathrm{t}} \quad$ : Tax Planning.

SIZE $_{\mathrm{t}} \quad$ : Ukuran perusahaan.

$\varepsilon_{t+1} \quad$ : residual regresi..

\section{HASIL PENELITIAN DAN PEMBAHASAN}

Tabel 1 Kriteria Sampel Penelitian

\begin{tabular}{clcc}
\hline No & \multicolumn{1}{c}{ Keterangan } & $\begin{array}{c}\text { Jumlah } \\
\text { Perusahaan }\end{array}$ & $\begin{array}{c}\text { Data } \\
\text { Observasi }\end{array}$ \\
\hline $\mathbf{1}$ & $\begin{array}{l}\text { Perusahaan transportasi yang terdaftar di BEI } \\
\text { pada tahun 2014-2018 }\end{array}$ & 35 & 175 \\
$\mathbf{2}$ & $\begin{array}{l}\text { Perusahaan transportasi yang delisting pada } \\
\text { tahun 2014-2018 }\end{array}$ & $(19)$ & $(95)$ \\
$\mathbf{3}$ & $\begin{array}{l}\text { Perusahaan transportasi yang konsisten listing } \\
\text { dan tidak memiliki data lengkap }\end{array}$ & $(2)$ & $(10)$ \\
\hline & Total sampel perusahaan yang digunakan & 14 \\
\hline
\end{tabular}

Sampel yang digunakan oleh penulis dalam riset ini dimana mempertimbangkan tiga kriteria sampel yang sudah ditentukan di awal yaitu perusahaan tranpostasi terdaftar di Bursa Efek Indonesia (BEI) pada tahun 2014-2018 yang dikurangi dengan daftar perusahaan tranposrtasi yang delisting pada tahun 2014-2018 dan daftar perusahaan transportasi yang listing pada 2014-2018 tetapi tidak memiliki data lengkap sesuai dengan variabel. Sehingga terdapat 14 perusahaan transportasi yang menjadi sampel penelitian penulis dengan 70 data observasi yaitu laporan keuangan perusahaan pada tahun 2014-2018. 


\begin{tabular}{ccccc}
\multicolumn{5}{c}{ Tabel 2 Statistik Deskriptif } \\
\hline Pinimum & Maximum & Mean & Std. Deviation \\
\hline AbnCF & $-3,20 \mathrm{E}+12$ & $1,40 \mathrm{E}+12$ & $-1,3694 \mathrm{E}+11$ & $5,66664 \mathrm{E}+11$ \\
AbnPROD & $-52,74$ & $-0,10$ & $-1,2337$ & 6,25690 \\
AbnDISEXP & $-92,52$ & 2,95 & $-1,9534$ & 11,00241 \\
DACC & 0,01 & 2,35 & 0,0616 & 0,27980 \\
TaxPlan & $-0,51$ & 3,55 & 0,0407 & 0,61067 \\
Size & $-3,65$ & 6,30 & 0,0427 & 1,09402 \\
\hline
\end{tabular}

Sumber: Hasil olah data penulis

Sementara itu, di dalam uji statistik deskriptif, berdasarkan tabel statistik deskriptif di atas, variabel persistensi laba (PTBIt+1), memiliki nilai minimum -3,20E+12 dan nilai maksimum 1.40E+12, dan nilai rata-rata $-1.3694 \mathrm{E}+11$. Standar deviasi dari persistensi laba yaitu 5,66664E+11 menunjukkan bahwa keragaman sampel besar.

Variabel abnormal cash flow from operation (AbnCFO) memiliki nilai minimum -52,75 dan nilai maksimum $-0,10$, dan nilai rata-rata -1,2337. Standar deviasi dari AbnCFO yaitu 6,25690 menunjukkan bahwa keragaman sampel besar. Variabel abnormal production (AbnPROD) memiliki nilai minimum $-92,52$ dan nilai maksimum 2,95 , dan nilai rata-rata $-1,95534$. Standar deviasi dari AbnPROD yaitu 11,00241 menunjukkan bahwa keragaman sampel besar.

Variabel abnormal discretionary expense (AbnDISEXP) memiliki nilai minimum 0,01 dan nilai maksimum 2,35, dan nilai rata-rata 0,0616. Standar deviasi dari AbnDISEXP yaitu 0,27980 menunjukkan bahwa keragaman sampel besar. Variabel tax planning (TaxPlan) memiliki nilai minimum -3,65 dan nilai maksimum 6,30, dan nilai rata-rata 0,0427. Standar deviasi dari TaxPlan yaitu 1,09402 menunjukkan bahwa keragaman sampel besar. Variabel ukuran perusahaan (SIZE) memiliki nilai minimum 20,37 dan nilai maksimum 29,46, dan nilai rata-rata 25,3143. Standar deviasi dari SIZE yaitu 2,28386 menunjukkan bahwa keragaman sampel kecil.

Tabel 3

Hasil Uji Hipotesis 1 (Model Summary)

\begin{tabular}{ccc}
\hline $\mathbf{R}$ & R Square & Adjusted R Square \\
\hline 0,402 & 0,162 & 0,096 \\
\hline \multicolumn{3}{c}{ Sumber: Hasil olah data penulis }
\end{tabular}

Tabel 4. Hasil Uji Hipotesis 1 (Koefisien)

\begin{tabular}{cccc}
\hline TaxPlan $_{t}=\alpha_{0}+\alpha_{1} A_{b n}$.CFO & \\
\hline Variabel & Standardized Coefficients & t-Statistic & Sig. \\
\hline Konstanta & & 1,376 & 0,174 \\
AbnCFO & $-6,096$ & $-0,925$ & 0,358 \\
AbnPROD & 5,832 & 1,425 & 0,159 \\
AbnDISEXP & $-0,176$ & $-0,066$ & 0,948 \\
DACC & $-0,132$ & $-0,797$ & 0,428 \\
SIZE & $-0,168$ & $-1,444$ & 0,154 \\
\hline
\end{tabular}

Sumber: Hasil olah data penulis

Nilai R Square 0,162 yang berarti variabel independen dapat dijelaskan oleh variabel dependen sebesar 16,2 persen dan sisanya dijelaskan oleh variabel lain. Hal ini berarti pengaruh variabel independen terhadap variabel dependen berada di posisi sangat lemah karena mendekati 0. Sementara 
Tabel 4.4 menunjukkan bahwa variabel-variabel di atas tidak ada satu pun proksi manajemen laba yang memiliki pengaruh signifikan terhadap karena nilai signifikansinya di atas 0,05 . Nilai t-Hitung<t-Tabel menyatakan bahwa tidak ada pengaruh yang signifikan antara variabel dependen tax planning dan variabel dependen manajemen laba.

Koefisien regresi AbnCFO yang bernilai negatif menunjukkan bahwa terdapat hubungan yang berlawanan arah dimana apabila nilai abnormal cash flow from operation naik maka nilai tax planning turun, dan sebaliknya. Hal ini juga serupa untuk variabel AbnDISEXP, DACC dan SIZE. Hal ini dapat terjadi dikarenakan aktivitas operasi kas yang tidak normal mempengaruhi sebagian besar transaksi perusahaan. Sehingga perencanaan pajak tidak dapat dilakukan dengan tepat karena terlalu banyak transaksi yang harus disusun sedemikian rupa.

Sedangkan koefisien Abn PROD yang bernilai positif menunjukkan bahwa terdapat hubungan searah dimana apabila nilai abnormal production naik maka nilai tax planning naik, dan sebaliknya. Hal ini dapat terjadi dikarenakan aktivitas produksi yang tidak normal mempengaruhi rencana penjualan perusahaan di masa depan, sehingga semakin tinggi ketidaknormalan di produksi akan mengakibatkan tingginya perencanaan pajak di tahun berjalan.

Kegiatan manajemen laba yang dilakukan oleh perusahaan tranportasi dalam kurun waktu 2014-2018, dari tindakan aliran kas dari operasi yang tidak normal, produksi yang tidak normal, beban diskresi yang tidak normal, dan kebijakan diskresi akrual tidak mempengaruhi tax planning. Hal ini konsisten dengan penelitian terdahulu oleh Syanthi et al (2012) dengan objek penelitian yang berbeda, dimana semua variabel independen tidak memiliki pengaruh yang signifikan terhadap variabel dependen. Oleh karena itu, hasil uji regresi linear berganda ini menolak H1.

Hasil penelitian ini menunjukkan bahwa tax planning tidak dapat diprediksi dengan menggunakan instrumen manajemen laba. Penulis menyadari bahwa dengan penggunaan pendekatan manajemen laba akrual dan manajemen laba riil dapat mempengaruhi hasil uji. Penulis menduga rendahnya nilai R Square karena disebabkan oleh fokus manajemen laba dan tax planning pada perusahaan sudah berbeda sehingga irisan yang ditemukan bernilai kecil. Kemudian, penulis juga menduga bahwa manajerial perusahan tidak memiliki dua orientasi yaitu manajemen laba dan tax planning di dalam sebuah laporan keuangan. Hal ini dikarenakan manajemen laba memiliki fokus pada mengatur nilai laba sedangkan tax planning berfokus pada nilai pajak, terutama kepada pembebanannya.

Tabel 4.5 menunjukkan nilai R Square 0,085 yang berarti variabel independen dapat dijelaskan oleh variabel dependen sebesar 8,5 persen dan sisanya dijelaskan oleh variabel lain. Hal ini berarti pengaruh variabel independen terhadap variabel dependen berada di posisi sangat lemah karena mendekati 0. Tabel 4.3 menunjukkan bahwa variabel AbnCFO, AbnPROD, AbnDISEXP, DACC, dan TaxPlan yang merupakan proksi manajemen laba tidak memiliki pengaruh signifikan terhadap karena nilanya di atas alpha 0,05 . Sementara hanya variabel kontrol SIZE yang signifikan pada 0,05 . Nilai t- 
Hitung $<\mathrm{t}-$ Tabel menyatakan bahwa manajemen laba tidak memiliki pengaruh signifikan terhadap persistensi laba.

\begin{tabular}{|c|c|c|}
\hline $\mathbf{R}$ & R Square & Adjusted R Square \\
\hline 0,292 & 0,085 & 0,014 \\
\hline
\end{tabular}

Tabel 6. Hasil Uji Hipotesis 2 (Koefisien)

\begin{tabular}{cccc}
\hline PTBI $_{\mathbf{t}+\mathbf{1}}=\alpha_{\mathbf{0}}+\alpha_{\mathbf{1}}$ Abn.CFO & $\boldsymbol{t}_{\mathbf{t}}+\alpha_{\mathbf{2}}$ Abn.PROD \\
\hline Variabel & Standardized Coefficients & $\boldsymbol{t} \boldsymbol{\alpha}_{\mathbf{3}}$-Statistic & \multicolumn{1}{c}{ Sig. } \\
\hline Konstanta & & 2,032 & 0,046 \\
\hline AbnCFO & 0,721 & 0,105 & 0,927 \\
\hline AbnPROD & $-0,094$ & $-0,022$ & 0,982 \\
\hline AbnDISEXP & 0,628 & 0,225 & 0,822 \\
\hline DACC & 0,056 & 0,326 & 0,745 \\
\hline SIZE & $-0,271$ & $-2,233$ & 0,029 \\
\hline
\end{tabular}

Sumber: Hasil olah data penulis

Koefisien regresi AbnPROD yang bernilai negatif menunjukkan bahwa terdapat hubungan yang berlawanan arah dimana apabila nilai abnormal production naik maka nilai persistensi laba turun, dan sebaliknya. Hal ini juga serupa untuk variabel SIZE. Hal ini dapat terjadi dikarenakan nilai produksi yang tidak normal mempengaruhi nilai laba di akhir tahun. Produksi yang tidak diimbangi dengan penjualan akan menyebabkan penumpukan persediaan yang berdampak pada laba, sehingga laba menjadi tidak persisten.

Sedangkan koefisien AbnCFO yang bernilai positif menunjukkan bahwa terdapat hubungan searah dimana apabila nilai abnormal cash flow from operation naik maka nilai persistensi laba naik, dan sebaliknya. Hal ini juga serupa untuk variabel AbnDISEXP dan DACC. Hasil ini tidak konsisten dengan teori persistensi laba dimana laba semakin persisten ketika terjadi aktivitas ekonomi perusahaan berjalan dengan normal. Penulis menduga bahwa ketidaknormalan di arus kas operasi perusahaan sudah diatasi sehingga perencanaan transaksi ke depan lebih baik.

Kegiatan manajemen laba yang dilakukan perusahaan transportasi di kurun waktu 2014-2018 tidak dapat membuktikan bahwa manajemen laba mempengaruhi persistensi laba. Hal ini tidak konsisten dengan penelitian terdahulu oleh Syanthi et al (2012) dengan objek penelitian yang berbeda, dimana variabel independen mempengaruhi variabel dependen. Oleh karena itu, hasil uji regresi linear berganda ini menolak $\mathrm{H} 2$.

Hasil penelitian ini menunjukkan bahwa persistensi laba tidak dapat diprediksi dengan menggunakan instrumen manajemen laba. Penulis menyadari bahwa dengan penggunaan pendekatan manajemen laba akrual dan manajemen laba riil dapat mempengaruhi hasil uji. Penulis menduga rendahnya nilai R Square karena disebabkan oleh fokus manajemen laba dan persistensi laba pada perusahaan sudah berbeda sehingga irisan yang ditemukan kecil nilainya. Hal ini menunjukkan bahwa baik metode akuntansi dan aktivitas operasional perusahaan tidak digunakan oleh agen untuk memberikan sinyal yang baik kepada principal. 
Secara umum, hasil penelitian tidak dapat membuktikan bahwa manajemen laba memiliki pengaruh terhadap tax planning dan persistensi laba. Walaupun demikian, penelitian ini memiliki kontribusi literasi terkait topik manajemen laba yang sampai saat ini belum ada peraturan perundangundangan yang mengatur. Implikasi praktis dari penelitian ini adalah bagi akuntan dan direksi keuangan untuk menaruh perhatian lebih akan dampak dari manajemen laba dan tax planning, terkhusus menjadikan laba tidak persisten. Terlebih kepada principal untuk memperhatikan sinyal yang diberikan oleh manajerial terkait performa laporan keuangan. Penelitian ini mendukung signaling theory dan agency theory dimana aktivitas manajemen laba dan tax planning menjadikan laba lebih persisten yang menjadi sinyal bagi principal atas asimetri informasi yang terjadi.

\section{KESIMPULAN DAN SARAN}

Penelitian ini memiliki tujuan untuk membuktikan bahwa manajemen laba memiliki pengaruh terhadap tax planning dan persistensi laba. Penelitian ini dilakukan atas dasar beberapa kasus keuangan yang melibatkan perusahaan transportasi yang sudah go public. Tax planning tidak dapat menjadi instrumen atau proksi terhadap manajemen laba dan tidak membuat laba menjadi lebih persisten. Penulis tidak berhasil membuktikan $\mathrm{H} 1$ dan $\mathrm{H} 2$ dikarenakan ada beberapa variabel penentu lain yang mempengaruhi tax planning dan persistensi laba, dimana peran manajerial dan metode pengakuan laba yang dilakukan oleh perusahaan menjadi penting. Hal ini diduga karena perusahaan yang berada di industri yang sama memiliki pengaturan manajemen yang tidak serupa satu sama lain, tetapi masih berada di koridor prinsip yang sama. Bahwa manajemen laba dan tax planning tidak dapat dilakukan secara bersamaan di dalam laporan keuangan di tahun berjalan karena fokus kebijakan manajemen menjadi terpecah.

Penelitian ini memiliki beberapa keterbatasan antara lain: (1) Penelitian ini hanya menggunakan sampel dari perusahaan di sektor transportasi sehingga tidak dapat dijadikan sebagai acuan untuk generalisasi mengenai manajemen laba, tax planning dan persistensi laba. (2) Penelitian ini hanya mengambil 14 sampel perusahaan di sektor industri secara 5 tahun (time-series) yang dimana sampel tidak cukup besar untuk diregresi secara linear yang menyebabkan munculnya data outlier. (3) Penelitian ini tidak dapat membuktikan bahwa manajemen laba mempengaruhi tax planning dan persistensi laba, sehingga penentuan sektor industri menjadi sangat penting karena berbeda industri akan memiliki metode yang berbeda dalam mencatatkan laba perusahaan.

Penulis menyarankan untuk penelitian selanjutnya: (1) Peneliti selanjutnya dapat mengembangkan suatu model yang dapat memprediksi tax planning dan persistensi laba dengan kecenderungan manajemen laba. (2) Peneliti selanjutnya dapat menggunakan variabel volatilitas arus kas dan tingkat hutang (Fanani, 2010) sebagai moderating atau intervening dalam melihat pengaruh persistensi laba dan undang-undang perpajakan dalam melihat pengaruh tax planning (Indrawati dan Budiwitaksono, 2015). 


\section{DAFTAR PUSTAKA}

Aditama, Ferry \& Purwaningsih, Anna. (2014). Pengaruh Perencanaan Pajak terhadap Manajemen Laba pada Perusahaan Nonmanufaktur yang Terdaftar di Bursa Efek Indonesia. MODUS. Vol.26 (1): 33-50, 2014.

Agustina, R. (2014). Real Earnings Management dengan Pendekatan Biaya Produksi Analisis Berdasarkan Sektor Industri Pada Perusahaan Manufaktur. Jurnal Ilmiah Akuntansi dan Humanika, 3(2).

Alareeni, Bahaaeddin \& Aljuaidi, Omar. (2014). The Modified Jones and Yoon Models in Detecting Earnings Management in Palestine Exchange (PEX). International Journal of Innovation and Applied Studies. 9. 2028-9324.

Ball, R., \& Shivakumar, L. (2008). Earnings quality at initial public offerings. Journal of accounting and economics, 45(2-3), 324-349.

Beneish, M. D. (2001). Earnings Management: A Perspective. SSRN Electronic Journal. doi:10.2139/ssrn.269625.

Beyer, Anne \& Guttman, Ilan \& Marinovic, Ivan. (2014). Earnings Management and Earnings Quality: Theory and Evidence. SSRN Electronic Journal. 10.2139/ssrn.2516538.

Charles W. Mulford; Eugene E. Comiskey. (2002). The Financial numbers game: detecting creative accounting practices. Charles W. Mulford and Eugene E. Comiskey. New York: John Wiley and Sons

Chen, Linda H. and Dhaliwal, Dan S. \& Trombley, Mark A., (2007). The Impact of Earnings Management and Tax Planning on the Information Content of Earnings. Available at SSRN: https://ssrn.com/abstract=1028808 or http://dx.doi.org/10.2139/ssrn.1028808

Connelly, Brian \& Certo, Trevis \& Ireland, R \& R. Reutzel, Christopher. (2011). Signaling Theory: A Review and Assessment. Journal of Management - J MANAGE. 37. 39-67. 10.1177/0149206310388419.

Darmawan, I Putu Edi et al. (2019). Accrual Earnings Management and Real Earnings Management: Increase or Destroy Firm Value? International Journal of Multicultural and Multireliqius Understanding.

Dwijayanto, Andy (2019). SCI Prediksi Sektor Transportasi Tumbuh 11,15\% di Tahun Ini. Dikutip 3 Juli 2019 dari Kontan: https://nasional.kontan.co.id/news/sci-prediksi-sektor-transportasi-tumbuh1115-di-tahun-ini

Fajri, Achmad \& Sekar Mayangsari. (2012). Pengaruh Perbedaan Laba Akuntansi dan Laba Pajak terhadap Manajemen Laba dan Persistensi Laba. Media Riset Akuntansi, Auditing \& Informasi, Vol. 12, No. 1, April 2012. 
Fanani, Zaenal. (2010). Analisis Faktor-Faktor Penentu Persistensi Laba. Jurnal Akuntansi dan Keuangan Indonesia Volume 7-No.1, Juni 2010.

Fern, R. H., Brown, B. C., \& Dickey, S. W. (1994). An Empirical Test Of Politically-Motivated Income Smoothing In The Oil Refining Industry. Journal of Applied Business Research (JABR), 10(1), $92-$ 100. https://doi.org/10.19030/jabr.v10i1.5967

Frankel, R., \& Litov, L. (2009). Earnings persistence. Journal of Accounting and Economics, 47(1-2), 182-190. doi:10.1016/j.jacceco.2008.11.008

Friana, Hendra .(2019). Bursa Efek Berikan Sanksi Denda Rp250 Juta ke Garuda Indonesia. Dikutip 1 Juli 2019: https://tirto.id/bursa-efek-berikan-sanksi-denda-rp250-juta-ke-garuda-indonesia-edgL

Hanlon, Michelle and Maydew, Edward L. and Shevlin, Terry J., (2006). Book-Tax Conformity and the Information Content of Earnings. Ross School of Business Paper No. 1029, Available at SSRN: https://ssrn.com/abstract=881561. or http://dx.doi.org/10.2139/ssrn.881561

Hsu, P.-H \& Hu, Xuesong. (2015). Advisory Board and Earnings Persistence. Journal of Accounting, Auditing \& Finance. 31. 10.1177/0148558X15571733.

Indrawati dan Gideon Setyo Budiwitaksono. (2015). Studi Faktor-Faktor Pemotivasi Manajemen Melakukan Tax Planning. Jurnal Akuntansi. Volume XIX, No.03, September 2015: 370-379.

Irawan, Karina Isna. (2019). Garuda Indonesia Didenda Rp 100 Juta dan Diminta Perbaiki Laporan Keuangan. Dikutip 1 Juli 2019 dari Harian Kompas Digital Premium: https://kompas.id/baca/ekonomi/2019/06/28/garuda-indonesia-didenda-rp-100-juta-dan-dimintaperbaiki-laporan-keuangan/

Irawan, Karina Isna dan M Clara Wresti. (2019). Kemenkeu: Audit Tak Sesuai Standar. Dikutip 1 Juli 2019 dari Harian Kompas Premium: https://kompas.id/baca/utama/2019/06/15/kemenkeu-audittak-sesuai-standar/

Jannag, Selfie Miftahul. (2019). Industri Transportasi Diprediksi Tumbuh 11 Persen pada 2019. Dikutip 3 Juli 2019 dari Tirto ID: https://tirto.id/industri-transportasi-diprediksi-tumbuh-11persen-pada-2019-djSc

Jiraporn, Pornsit \& A. Miller, Gary \& Yoon, Soon \& Kim, Young. (2008). Is Earnings Management Opportunistic or Beneficial? An Agency Theory Perspective. International Review of Financial Analysis. 17. 622-634. 10.1016/j.irfa.2006.10.005.

Kothari, S. P., Leone, A. J., \& Wasley, C. E. (2005). Performance matched discretionary accrual measures. Journal of Accounting and Economics, 39(1), 163-197. doi:10.1016/j.jacceco.2004.11.002

Lo, Kin. (2007). Earnings Management and Earnings Quality. Journal of Accounting and Economics. 45. 350-357. 10.1016/j.jacceco.2007.08.002. 
Marczyk, Geoffrey et al. (2005). Essentials of Research Design and Methodology. New Jersey: John Wiley \& Sons, Inc.

Mechelli, Alessandro dan Riccardo Cimini. (2013). How have the IAS/IFRS adoption affected earnings management in EU? The effect of the absence/divergence of regulation and of legal enforcement. Corporate Ownership and Control 11(1)

Myers, S. C., \& Majluf, N. S. (1984). Corporate financing and investment decisions when firms have information that investors do not have. Journal of financial economics, 13(2), 187-221.

Nadini, Widya (2018). Infrastuktur Transportasi Indonesia Terbaik Ketiga di ASEAN. Dikutip 3 Juli 2019 dari https://katadata.co.id/grafik/2018/10/08/infrastruktur-transportasi-indonesia-terbaikketiga-di-asean

Nurgaha, Erik. (2016). Faktor-Faktor yang Mempengaruhi Manajemen Laba dan Dampaknya terhadap Koefisien Respon Laba. Jurnal SIKAP, Vol 1 (No. 1), 2016, hal 9-21.

Puspita, Sari Ririn. (2019). Tax Planning as A Tax Avoidance Step in Indonesia. RJOAS, 6 (90), June 2019; DOI 10.18551/rjoas.2019-06.38.

Roychowdhury, Sugata, (2006). Earnings Management Through Real Activities Manipulation. Available at SSRN: https://ssrn.com/abstract=477941 or http://dx.doi.org/10.2139/ssrn.477941

Scott, W. R. (2015). Financial accounting theory (Seventh).

Shah, Ali, S. Z., Butt, S. A., \& Bin Tariq, D. (2011). Use or abuse of creative accounting techniques. International Journal of Trade, Economics and Finance, 2(6).

Shailer, Greg. (2018). Agency Theory. 10.1007/978-3-319-23514-1_151-1.

Suwandika, I Made Andi dan Ida Bagus Putra Astika. (2013). Pengaruh Perbedaan Laba Akuntansi, Laba Fiskal, Tingkat Hutang Pada Persistensi Laba. E-Jurnal Akuntansi Universitas Udayana 5.1.

Syanthi, Nila Trisna, Made Sudarma, \& Erwin Saraswati. (2012). Dampak Manajemen Laba Terhadap Perencanaan Pajak dan Persistensi Laba. Ekuitas: Jurnal Ekonomi dan Keuangan.

Toumeh, Ahmad \& Yahya, Sofri. (2019). A Review of Earnings Management Techniques: An IFRS Perspective. Global Business and Management Research: An International Journal. 11. 1-13.

Tyasari, Irma. (2009). Asimetri Informasi dan Praktik Manajemen Laba pada Perusahaan Manufaktur di Bursa Efek Indonesia. Modernisasi, Volume 5, Nomor 3, Oktober 2009.

Whelan, Jamie \& Demangeot, Catherine. (2015). Signaling Theory. 10.1002/9781118785317.weom090243.

Wresti, Maria Clara (2019). Laporan Keuangan Garuda Bermasalah. Dikutip 1 Juli 2019 dari Harian Kompas Premium: https://kompas.id/baca/ekonomi/2019/06/29/laporan-keuangan-garudabermasalah/, 29 Juni 2019 